\title{
PENINGKATAN PEMAHAMAN PESERTA DIKLAT KEPALA MADRASAH TENTANG HAK ASASI MANUSIA (HAM)
}

\author{
Dermawati \\ Pusdiklat Tenaga Teknis Pendidikan dan Keagamaan \\ Email: dermawatinazar@gmail.com
}

\begin{abstract}
Abstrak
Tujuan dari penelitian ini adalah untuk membandingkan pemahaman peserta Diklat Teknis Substantif Hak Asasi Manusia bagi Kepala Madrasah sebelum dan sesudah mengikuti pendidikan dan pelatihan di Pusdiklat Tenaga Teknis Pendidikan dan Keagamaan. Penelitian menggunakan pendekatan kuantitatif dengan metode kausal komparatif yang datanya dianalisis secara statistik deskriptif. Hasil dari penelitian ini secara keseluruhan terdapat peningkatan pemahaman yang signifikan peserta Diklat Teknis Substantif Hak Asasi Manusia bagi Kepala Madrasah setelah mengikuti pendidikan dan pelatihan yaitu pada mata diklat Konsep dasar Hak Asasi Manusia, Instrumen Nasional Hak Asasi Manusia, Instrumen Internasional Hak Asasi Manusia (The Internasional Bill of Human Rights), Badan-badan Hak Asasi Manusia, Pelanggaran Hak Asasi Manusia dan Mekanisme penanganannya, Manajemen Implementasi Program Hak Asasi Manusia, Menumbuhkan Budaya Organisasi, Kearifan Lokal, dan Kesadaran Berbangsa dan Bernegara, dan Metode Pembelajaran Efektif. Sedangkan untuk mata diklat Implementasi Pemenuhan Hak Asasi Manusia pemahaman peserta diklat tidak meningkat secara signfikan sebelum maupun sesudah diklat karena nilai t-hitung lebih kecil dari t-tabel.
\end{abstract}

Kata Kunci: Hak Asasi Manusia, pemahaman, peserta pendidikan dan pelatihan

\begin{abstract}
The purpose of this study was to compare the understanding of participants in the Technical Training of Substantive Human Rights for the Head of Madrasah before attending training and education at the Education and Religious Technical Training Center. The study uses quantitative with comparative causal methods whose data are analyzed descriptively statistically. Training on Technical Substantive Human Rights for Madrasah Heads after attending education and training on basic subjects of Human Rights, National Human Rights Instruments, International Instruments for Human Rights (International) Human Rights Bill), Human Rights Bodies, Violations Human Rights and Security Policies, Management Programs for the Implementation of Human Rights, Cultivating Cultural Organizations, Local Wisdom, and National and State Awareness, and Effective Learning Methods. Meanwhile for the subject of the Training for the Implementation of Human Rights Fulfillment, the training participants did not increase significantly before finally being finalized by the training because the $t$-count value was smaller than t-table.
\end{abstract}

Keywords: Human Rights, understanding, education and training participants 


\section{PENDAHULUAN}

$S$ esuatu yang sangat penting dalam kehidupan umat manusia yang mutlak harus dimiliki adalah Hak asasi manusia (HAM), yang sudah melekat sejak lahir. Hak asasi masingmasing individu tidak dapat diganggu oleh orang lain. Maka dari itu, hak asasi harus dipahami oleh setiap individu dalam kehidupan sosial dan masyarakat. Karena begitu pentingnya, HAM dijadikan sebagai salah satu materi dalam jenjang pendidikan berupa materi tentang Pendidikan Pancasila dan Kewarganegaraan. Oleh sebab itu untuk menjadi warga negara yang baik harus memahami dan menyadari mengenai hak asasi manusia.

Menurut UU No. 39 Tahun 1999, menyatakan bahwa hak asasi manusia merupakan hak-hak dasar yang secara kodrati melekat pada diri manusia, bersifat universal dan langgeng, oleh karena itu harus dilindungi, dihormati, dipertahankan dan tidak boleh diabaikan, dikurangi, atau dirampas oleh siapapun.

Selanjutnya dalam Pasal 28 UUD 1945, dalam menentukan kewajiban dasar dari manusia: 1) Setiap orang wajib menghormati hak asasi manusia lain dalam tertib kehidupan bermasyarakat, berbangsa dan bernegara; 2) Dalam menjalankan hak dan kebebasannya, setiap orang wajib tunduk kepada pembatasan yang ditetapkan dengan undang-undang dengan maksud sematamata untuk menjamin pengakuan serta penghormatan atas hak dan kebebasan orang lain dan untuk memenuhi tuntutan yang adil sesuai pertimbangan moral, nilai-nilai agama, keamanan, dan ketertiban umum dalam suatu masyarakat demokratis.

Sejak ditetapkannya Universal Declaration of Human Rights (UDHR) atau Deklarasi Universal Hak Asasi Manusia (DUHAM) pada tahun 1948, manusia hidup dalam kebebasan, persamaan dan perlindungan. Setiap orang diakui hak dasarnya. Semua orang tanpa terkecuali untuk mengakui hak dasar atau kodrati orang lain, termasuk negara beserta penguasanya sekalipun.

Menurut Supriyanto Abdi (2007: 7475) dalam mengurai kompleksitas hubungan Islam, HAM dan Barat ada tiga varian pandangan tentang hubungan Islam dan hak asasi manusia baik yang dikemukakan oleh para sarjana Barat maupun Muslim sendiri, yakni : pertama, menegaskan bahwa has asasi manusia tidak sesuai dengan gagasan dan konsepsi hak asasi manusia modern. Kedua, menyatakan bahwa Islam menerima semangat kemanusiaan hak asasi manusia modern, tetapi pada saat yang sama menolak landasan sekulernya dan menggantinya dengan landasan Islam. Ketiga, menegaskan bahwa hak asasi manusia modern adalah khazanah kemanusiaan universal dan Islam bisa memberikan landasan normatif yang sangat kuat.

Indonesia merupakan negara yang mendeklarasikan kemerdekaan 3 tahun lebih dahulu sebelum ditetapkan DUHAM 1948. Negara Indonesia sangat memperhatikan penegakan HAM. Dalam upaya memberikan jaminan atas penegakan HAM, materi muatan HAM dimasukkan dalam Amandemen Kedua UUD 1945, pemerintah harus senantiasa menjamin eksistensi hak-hak dasar setiap 
warga negaranya. Pelanggaran tentang hak asasi warga negara dapat dikatakan sebagai pelanggaran HAM. Maka dari itu Pemerintah bertanggungjawab terhadap hak asasi dalam segala bidang, seperti dalam Pasal 72 UU RI Nomor 39 Tahun 1999 tentang Hak Asasi Manusia yaitu "Kewajiban dan tanggung jawab Pemerintah sebagaimana dimaksud dalam Pasal 71, meliputi langkah implementasi yang efektif dalam bidang hukum, politik, ekonomi, sosial, budaya, pertahanan keamanan negara, dan bidang lain". Dengan kata lain, pemerintah harus memenuhi dan menjamin hak sipil politik (sipol) dan hak ekonomi, sosial, budaya (ekosob).

Berdasarkan penjelasan di atas dan UU serta UUD 1945 maka terlihat begitu pentingya pengetahuan tentang Hak Asasi Manusia dipahami dan diimlementasikan oleh segenap masyarakan Indonesia.

Dalam kehidupan bermasyarakat di Indonesia, persoalaan-persoalan mendasar HAM di Indonesia antara lain: 1) Landasan solid HAM; Kebijakan antar rezim; Perubahan aktor Pelanggar HAM; Fokus besar dan keterlambatan; dan Topeng penyelamatan demi Indonesia atau keanggan pencirian terhadap kekhasan Indonesia seakan membentengi nilai-nilai universal HAM untuk diterapkan (Yuliarso \& Prajarto, 2005: 296-303).

Mengingat pentingnya hal tersebut maka Pusdiklat Tenaga Teknis Pendidikan dan Keagamaan telah menyusun kurikulum tentang Diklat Teknis Substantif tentang Hak Asasi Manusia. Dengan tersusunnya kurikulum tersebut maka diadakanlah Pendidikan dan Pelatihan untuk Kepala Madrasah.
Dipilihnya Kepala Madrasah sebagai peserta diklat karena bisa langsung bisa mengimplementasikan di madrasahmadrasah yang mereka pimpin dan juga sosialisasi ke masyarakat lainnya untuk percepatan penerapan HAM.

Tujuan dari penelitian ini adalah untuk membandingkan pemahaman peserta diklat Teknis Substantif Hak Asasi Manusia Bagi Kepala Madrasah sebelum mengikuti diklat dengan sesudah diklat di Pusdiklat Tenaga Teknis Pendidikan dan Keagamaan.

Pemahaman tersebut meliputi materi pada mata diklat Konsep Dasar Hak Asasi Manusia, Instrumen Nasional Hak Asasi Manusia, Instrumen Internasional Hak Asasi Manusia (The Internasional Bill of Human Rights), Badan-Badan Hak Asasi Manusia, Implementasi Pemenuhan Hak Asasi Manusia Pelanggaran Hak Asasi Manusia dan Mekanisme penanganannya, Manajemen Implementasi Program Hak Asasi Manusia, Menumbuhkan Budaya Organisasi, Kearifan Lokal, dan Kesadaran Berbangsa dan Bernegara, dan Metode Pembelajaran Efektif.

Untuk memperjuangkan apa yang yang dianggap sebagai haknya, dalam sejarah manusia telah banyak kejadian di mana seseorang atau kelompok manusia mengadakan perlawanan terhadap penguasa atau golongan lainnya. Dalam semua ajaran agama di dunia telah diajarkan perlindungan dan jaminan terhadap hak-hak manusia, sebagai tuntutan moral baik dalam ajaran Islam, Hindu, Khong Hu Cu, Budha, Injil, yang intinya adalah manusia sederajad. Tapi dengan kekuasaan manusia menindas manusia lainnya dalam kenyataan manusia selalu berperang untuk 
menaklukan/ menghancurkan manusia satu dengan lainnya.

Pemikiran dan perjuangan tentang hak asasi manusia telah tercermin dari dahulu kala berupa ajaran tokoh-tokoh Junani, Romawi, maupun masa abad pertengahan, masa Renaisanse (pembaharuan dan pencerahan) sampai dcwasa ini, dan tidak terlepas dari konsep hubungan Negara dengan warganegaranya.

Seorang tokoh Yunani abad ke 6 sebelum masehi yang bernama Solon menganjurkan untuk diadakan perubahan dan pembaharuan dengan membuat undang-undang agar para budak diberi kemerdekaan, kemudian membentuk badan keadilan yang disebut Heliasa, dan majelis rakyat yang disebut Ecelessia. Menurut Naning (1982: 8), nampak ada pemikiran tentang triaspolitika pada masa ini. Socrates (470-399 Sebelum masehi) dan muridnya Plato (420-348), yang menganjurkan masyarakat untuk melakukan sosial kontrol kepada pemerintah yang zalim dan tidak mengakui nilai-nilai keadilan dan kebenaran.

Orang Romawi terkenal dengan cara berfikir yuridis dogmatis dan praktis dengan teori ketatanegaraannya banyak diterapkan dalam praktek ketatanegaraannya. Kodifikasi hukum yang pertama yang mereka lakukan yakni UU 12 Meja (tahun 450 sebelum masehi) di mana tiap-tiap meja mengatur niasalah tertentu, misalnya jual beli perkawinan, warisan dan sebagainya. Tujuan UU 12 Meja adalah untuk adanya jaminan kepastian hukum dalam masyarakat. Ada 4 fase perkembangan ketatanegaraan Romawi, yakni, masa kerajaan kecil
(Negara Kota), masa Negara demokrasi (masih Negara kota), masa Principati (luas Negara semakin luas tetapi masih ada ciri demokrasi dengan adanya badan perwakilan rakyat dan eksekutifoya sebagai mandataris dari badan perwakilan rakyat), dan kemudian berkembang menjadi Kekaisaran dimana raja berkuasa absolute. Kaisar Justinianus (527-565 sesudah masehi) melakukan kodifikasi hukum yang kedua, yang terkenal dengan Corpus luris Civilis yang terdiri dari empat (4) buku, yang merupakan cikal bakal kitab undang-undang hukum perdata (Kode Napoleon). Konsep hukum Romawi inilah yang kemudian dikembangkan pada masa pembaharuan (Renaisance) 8 yang berkaitan dengan masalah yang ditulis.

Konsep hukum dari Romawi ini akhirnya berkembang ke seluruh penjuru dunia termasuk Indoesia. Pengertian Hak dalam hak asasi manusia adalah suatu lingkungan keadaan atau daerah kebebasan bertindak di mana pemerintah tidak mengadakan pembatasannya, sehingga membiarkan individu atau perseorangan untuk memilih sendiri menggunakannya atau tidak". Melihat pengertian ini maka hak mengandung arti membatasi kekuasaan berdaulat dari pemerintah (Sumana, 1970: 5).

Lebih lanjut menurut Romdlan Naning dalam Utari (2016:14) menyatakan bahwa hak asasi manusia adalah hak yang melekat pada martabat manusia yang melekat padanya sebagai insan ciptaan Allah Yang Maha Kuasa. Hak-hak asasi manusia merupakan hakhak yang dimiliki manusia menurut kodratnya, yang tidak dapat dipisahkan dari hakekatnya. 
Hak bukanlah kebebasan absolut ada pembatasannya, yakni undang-undang. Sehingga pada saat akan menggunakan hak-hak, maka pada saat yang sama harus juga diperhatikan apa kewajiban yang ditetapkan oleh undang-undang. Di sini fungsi hukum (undang-undang) adalah di satu sisi melindungi hak asasi manusia dan di sisi lain membatasi hak asasi manusia.

Hak asasi manusia adalah sebagai hak-hak yang sedemikian rnelekat pada sifat manusia, sehingga tanpa hak-hak itu kita tidak mempunyai martabat sebagai manusia (inheirent dighnity). Oleh karena itu pula hak-hak tersebut tidak boleh dilanggar atau dicabut. Ramdlon Naning: "Hak asasi manusia adalah hak yang melekat pada martabat manusia yang melekat padanya sebagai insan ciptaan Allah Yang Maha Kuasa. Hak-hak asasi manusia merupakan hak-hak yang dimiliki manusia menurut kodratnya,yang tidak dapat dipisahkan dari hakekatnya." Miriam Budiardjo: "Hak asasi manusia adalah hak yang dimiliki manusia yang diperoleh dan dibawanya bersamaan dengan kelahirannya atau kehadirannya di dalam kehidupan masyarakat. Dianggap bahwa beberapa hak itu dimilikinya tanpa perbedaan atas dasar bangsa, ras, agama atau kelamin, dan karena itu bersifat universal. Dasar dari semua hak asasi ialah bahwa manusia memperoleh kesempatan berkembang sesuai dengan bakat dan cita-citanya. (Reksodiputro, 1994: 4).

Indonesia dalam mencapai Standar Internasional HAM harus membenahi kondisi HAM, hal ini menjadi semakin sulit ketika harus disertai pula dengan langkah lain yang tidak ringan dalam bentuk perwujudan good governance dan pelaksanaan demokrasi guna mencapai democratic governance (Yuliarso \& Prajarto, 2005: 304-306). Sebagai remedi untuk negara-negara yang berada pada kondisi kritis harus memiliki beberapa keterbatasan yang harus disiasati yaitu antara lain: secara psikis democratic governance harus sengaja dibentuk sebagai suatu prasyarat atau usaha memenuhi standar formal dalam Percaturan internasional dan bukan karena sebuah keyakinan murni atas nilai dan manfaatnya; terjadi bila ruang cakupannya berubah atau mengalami pergeseran; HAM dipandang memiliki karakter universal dan internasional, good governance mungkin belum sampai kepada pandangan sebagai nilai yang universal; copy program dari penerapan good governance dari satu negara ke negara yang lain kemungkinan justru menghasilkan pemujaan terhadap program itu, tanpa diikuti pemahaman untuk menerapkan substansinya di setiap tingkat pemerintahan; dan dan penerimaan good governance, demokrasi, HAM dan hingga ke democratic governance karena agenda media dan agenda publik cendrung untuk tidak terlalu memerhatikannya.

\section{METODE PENELITIAN}

Penelitian ini menggunakan
pendekatan kuantitatif dengan
menggunakan metode kausal komparatif
yang datanya dianalisis secara statistik
deskriptif. Menurut Sukardi (2008: 165),
penelitian ex-post facto atau penelitian
kausal komparatif berarti penelitian
dimana peneliti berusaha menentukan
penyebab atau alasan, untuk keberadaan


perbedaan dalam perilaku atau status dalam kelompok individu.

Data dalam penelitian ini diolah dengan cara statistik deskriptif yaitu statistik yang berfungsi untuk mendeskripsikan atau memberi gambaran terhadap obyek yang diteliti melalui data sampel sebagaimana adanya, tanpa melakukan analisis dan memuat kesimpulan yang berlaku untuk umum (Sugiyono, 2010: 29).

Untuk mengetahui ada tidaknya perbedaan pemahaman Peserta Diklat terhadap Mata Diklat sebelum dengan sesudah diklat maka digunakan uji hipotesis dengan asumsi:

$$
\begin{aligned}
& H_{0}=\mu_{i}-\mu_{0}=0 \\
& H_{1}=\mu_{i}-\mu_{0} \neq 0
\end{aligned}
$$

Untuk menentukan perbedaan nilai ratarata sampel yang signifikan sebelum dan sesudah diklat maka digunakan uji-t. Jika nlai t-hitung>t-tabel, berarti nilai ratarata kedua sampel tersebut mempunyai perbedaan yang signifikan artinya $\mathrm{HO}$ ditolak.

Untuk mencari t-hitung digunakan persamaan di bawah ini (Bass, 2007:137).

$$
t=\frac{n(x 1-x 2)-\delta 0}{s}
$$

$\bar{X}_{1=\text { Nilai rata-rata sampel } 1}$

$\overline{\mathrm{X}}_{2}=$ Nilai rata-rata sampel 2

$\delta_{0}=$ perbedaan rata-rata dua sampel berdasarkan hipotesis

$\mathrm{s}=$ standar deviasi

Subyek dalam penelitian ini adalah peserta Diklat Teknis Substantif HAM bagi Kepala Madrasah sebanyak 30 orang. Penelitian dilakukan di Pusdiklat Tenaga
Teknis Pendidikan dan Keagamaan pada tanggal 4-10 Maret tahun 2019.

Data dalam penelitian ini didapatkan dengan cara memberikan angket dan wawancara terstruktur kepada peserta Diklat Teknis Substantif HAM bagi Kepala Madrasah .

Angket terdiri dari pernyataanpernyataan tentang indikator mata diklat dengan pilihan jawaban yaitu:

$\mathrm{SB}=$ Sangat Baik= skor 5 ,

$\mathrm{B}=$ Baik = skor 4 ,

$\mathrm{C}=$ Cukup $=$ skor 3 ,

$\mathrm{K}=$ Kurang $=$ skor 2 , dan

$\mathrm{TT}=$ Tidak Tahu $=$ skor 1

Perolehan hasil angket ditentukan nilai minimum, nilai maximum, Mean, Median. Rata-rata sampel tiap mata diklat, nilai minimum, maximum, mean dan median dikategorikan dengan interval nilai:

Rata-rata 1.0-1.7 = tidak tahu

Rata-rata 1.8-2.5 = kurang

Rata-rata 2.6-3.3 = cukup

Rata-rata 3.4-4.1 = baik

Rata-rata 4.2-5.0 = sangat baik

Sedangkan standar deviasi merupakan kumpulan data sama dengan nol menunjukkan bahwa semua nilai-nilai dalam himpunan tersebut adalah sama. Sebuah nilai deviasi yang lebih besar akan memberikan makna bahwa titik data individu jauh dari nilai rata-rata.

\section{TEMUAN DAN PEMBAHASAN}

\section{Temuan}

Dalam penelitian ini yang diteliti adalah peserta Diklat Teknis Substantif HAM bagi Kepala Madrasah yang diikuti oleh 30 orang peserta yang merupakan perwakilan dari 30 provinsi di Indonesia 
dari tanggal 4-10 Maret 2019 antara lain menerima materi antara lain :

a. Konsep dasar HAM yang indikator materi yang diberikan adalah Pengertian HAM, Karakteristik HAM; Nilai-nilai HAM, Ruang lingkup HAM; Sejarah perkembangan HAM internasional; Prinsip HAM dalam hukum internasional, Subyek hukum HAM; Sumber hukum HAM; Pelanggaran HAM; Pertanggungjawaban negara.

b. Mata Diklat Instrumen Nasional HAM yang indikator materinya antara lain Hak untuk hidup; Hak berkeluarga, Hak melanjutkan keturunan; Hak mengembangkan diri; Hak kebebasan pribadi; Hak Kebebasan Pribadi; dan Hak atas rasa aman.

c. Mata Diklat Instrumen Internasional HAM (The Internasional Bill of human Rights), membahas indikator materi tentang The International Bill of Human Rights; Deklarasi universal Hak-Hak Asasi Manusia, Kekuatan hukum deklarasi universal Hak Asasi Manusia.

d. Mata Diklat Badan-Badan Hak Asasi Manusia, terdiri dari materi Badanbadan Hak Asasi Manusia PBB; Badan-badan yang didirikan Berdasarkan Instrumen-instrumen Hak Asasi Manusia; Badan-badan Khusus PBB, Badan-badan Nasional Hak Asasi Manusia.

e. Mata Diklat Implementasi Pemenuhan HAM, indikator materinya antara lain Jaminan implementasi pemenuhan HAM, Mekanisme kerja implementasi pemenuhan HAM; Implementasi HAM; Evaluasi dan pelaporan; Permasalahan strategis, rencana aksi, indikator implementasi pemenuhan HAM,

f. Mata Diklat Pelanggaran HAM dan Mekanisme penanganannya, terdiri dari materi Pengertian pelanggaran HAM; Pelanggaran HAM dalam perspektif instrumen nasional; Pelanggaran HAM dalam perspektif instrumen internasional; Pertanggungjawaban Negara atas terjadinya pelanggaran HAM; Pertanggungjawaban Individual atas terjadinya pelanggaran HAM, Pertanggungjawaban Komando atas terjadinya pelanggaran HAM; Pengadilan Hak Asasi Manusia atas terjadinya pelanggaran HAM, Mekanisme penanganan pelanggaran HAM Berat; serta Peran Ditjen HAM Kementerian Hukum dan HAM RI dalam penanganan pelanggaran

g. Mata Diklat Manajemen Implementasi Program HAM, indikator materinya adalah Penyusunan rencana implemetasi program HAM; Implementasi program HAM, Control terhadap implementasi program HAM, Evaluasi implemetasi program HAM.

h. Mata Diklat Menumbuhkan Budaya Organisasi Berbasis HAM; terdiri dari indikator materi Budaya organisasi berbasis HAM; Kearifan Lokal, dan Kesadaran Berbangsa dan Bernegara, Konsep kearifan lokal; kesadaran berbangsa dan bernegara; Pentingnya budaya lokal dalam membangun kesadaran berbangsa dan bernegara.

i. Mata Diklat Metode Pembelajaran Efektif mengenai HAM terdiri dari indikator materi antara lain Konsep, 
asumsi dasar dan prinsip pembelajaran orang dewasa; Metode dan strategi efektif dalam pembelajaran HAM; Simulasi metode efektif dalam pembelajaran HAM.

Dalam penelitian ini dianalisis pemahaman peserta diklat berdasarkan persepsi masing-masing sebelum menerima materi dan sesudah menerima materi pada mata diklat yang tersebut di atas.

Dari angket yang diisi oleh peserta diklat maka didapatkan hasil seperti pada Tabel 1.

Tabel 1. Pemahaman Peserta Diklat terhadap Mata Diklat Konsep dasar HAM

\begin{tabular}{|l|c|c|}
\hline $\begin{array}{c}\text { Hasil } \\
\text { Pemahaman }\end{array}$ & $\begin{array}{c}\text { Sebelum } \\
\text { diklat }\end{array}$ & $\begin{array}{c}\text { Sesudah } \\
\text { diklat }\end{array}$ \\
\hline Minimum & 1,8 & 3,9 \\
\hline Maximum & 2,5 & 4,5 \\
\hline Mean & 2,0 & 4,2 \\
\hline Median & 2,0 & 4,2 \\
\hline
\end{tabular}

Dari tabel 1 tentang pemahaman peserta diklat terhadap mata diklat Konsep dasar HAM terlihat bahwa sebelum diklat nilai minimum 1,8 , maximum 2,5 dengan rata-rata 2,0 serta nilai sesudah diklat nilai minimum 3,9 , maximum 4,5 dengan rata-rata 4,2.

Dari hasil uji-t di dapatkan t-hitung $=11,90, \quad$ P-Value $=0,000$, Standar Deviasi $=0,6381$ sedang $t$-tabel 0,681 , dengan $a=0.5$ untuk pengujian dua sisi.

Untuk lebih jelasnya dapat dilihat pada diagram 1.

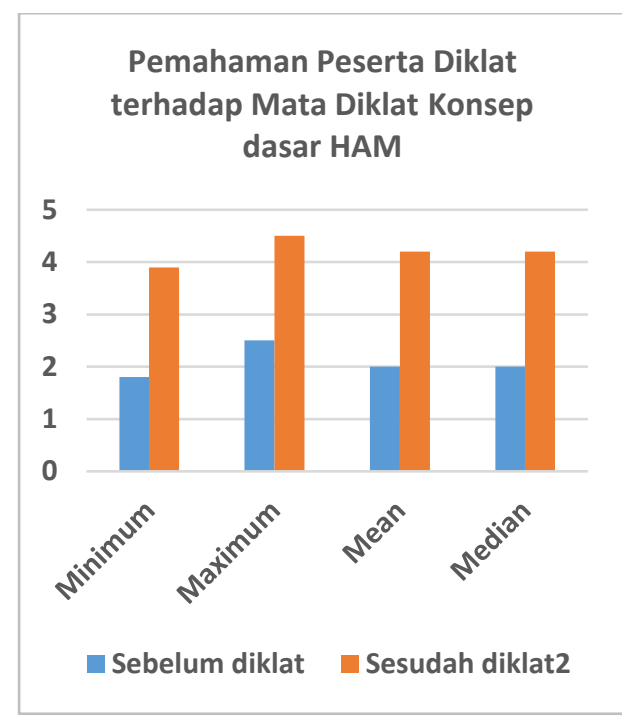

Diagram 1. Pemahaman Peserta Diklat terhadap Mata Diklat Konsep dasar HAM

Hasil angket tentang Pemahaman Peserta Diklat terhadap Mata Diklat Instrumen Nasional HAM dapat dilihat pada Tabel 2.

Tabel 2. Pemahaman Peserta Diklat terhadap Mata Diklat Instrumen Nasional HAM

\begin{tabular}{|l|c|c|}
\hline $\begin{array}{c}\text { Hasil } \\
\text { Pemahaman }\end{array}$ & $\begin{array}{c}\text { Sebelum } \\
\text { diklat }\end{array}$ & $\begin{array}{c}\text { Sesudah } \\
\text { diklat }\end{array}$ \\
\hline Minimum & 2,4 & 4,4 \\
\hline Maximum & 2,7 & 4,5 \\
\hline Mean & 2,6 & 4,4 \\
\hline Median & 2,6 & 4,5 \\
\hline
\end{tabular}

Pada tabel 2 tentang pemahaman peserta diklat terhadap mata diklat Instrumen Nasional HAM nilai pemahaman sebelum diklat nilai minimum 2,4 , maximum 2,7 dengan rata-rata 2,6. Dan nilai sesudah diklat nilai minimum 4,4 , maximum 4,5 dengan rata-rata 4,4.

Hasil uji-t di dapatkan t-hitung $=$ 8,19 , P-Value $=0,000$, Standar Deviasi 
$=0,7959$, sedang t-tabel 0,681 , dengan $a=0.5$ untuk pengujian dua sisi.

Lebih jelas tentang pemahaman peserta diklat tentang Instrumen Nasional HAM dapat dilihat pada diagram 2 .

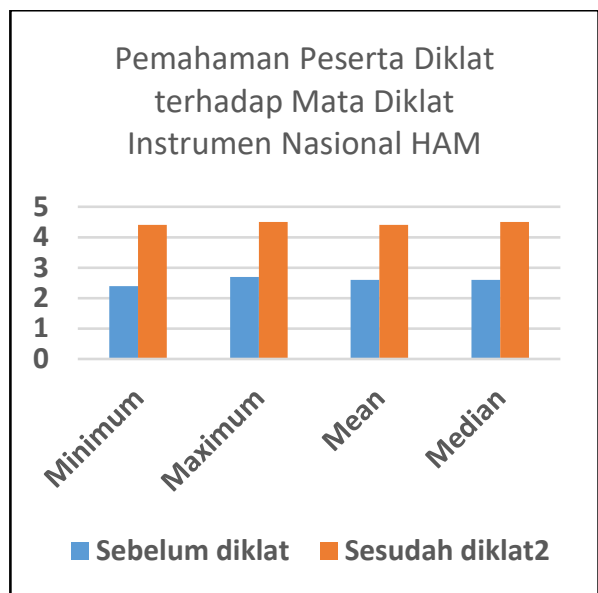

Diagram 2. Pemahaman Peserta Diklat terhadap Mata Diklat Instrumen Nasional HAM

Hasil angket tentang Pemahaman Peserta Diklat terhadap Mata Diklat Instrumen Internasional HAM (The Internasional Bill of human Rights) dapat dilihat pada Tabel 3.

Tabel 3. Pemahaman Peserta Diklat terhadap Mata Diklat Instrumen Internasional HAM (The Internasional Bill of human Rights)

\begin{tabular}{|l|c|c|}
\hline $\begin{array}{c}\text { Hasil } \\
\text { Pemahaman }\end{array}$ & $\begin{array}{c}\text { Sebelum } \\
\text { diklat }\end{array}$ & $\begin{array}{c}\text { Sesudah } \\
\text { diklat }\end{array}$ \\
\hline Minimum & 1,8 & 4,2 \\
\hline Maximum & 2,0 & 4,2 \\
\hline Mean & 1,9 & 4,2 \\
\hline Median & 1,9 & 4,2 \\
\hline
\end{tabular}

Pada tabel 3 tentang pemahaman peserta diklat terhadap mata diklat iklat Instrumen Internasional HAM (The
Internasional Bill of human Rights) nilai pemahaman sebelum diklat nilai minimum 1,8 , maximum 2,0 dengan rata-rata 1,9 . Dan nilai sesudah diklat nilai minimum 4,2, maximum 4,2 dengan rata-rata 4,2. Dari hasil uji-t di dapatkan thitung $=9,59$, P-Value $=0,000$, Standar Deviasi $=0,8329$, sedang t-tabel 0,681 , dengan $a=0.5$ pada pengujian dua sisi.

Tabel 3 dapat dijelaskan dengan melihat diagram 3.

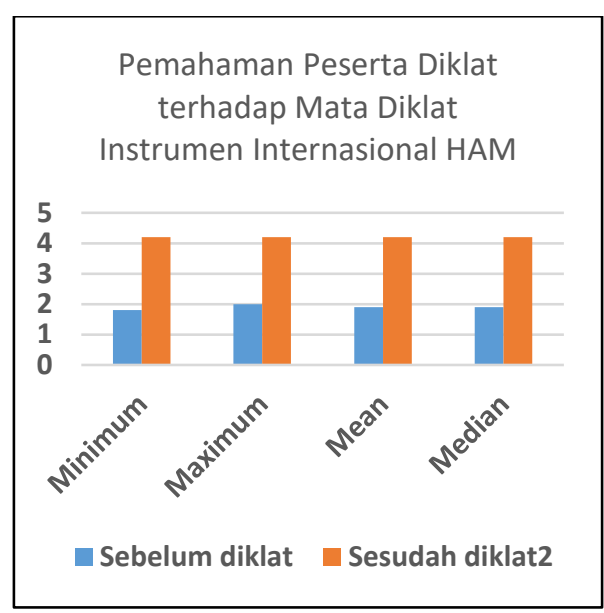

Dagram 3. Pemahaman Peserta Diklat terhadap Mata Diklat Instrumen Internasional HAM (The Internasional Bill of human Rights)

Hasil angket tentang Pemahaman Peserta Diklat terhadap Mata Diklat Badan-Badan Hak Asasi Manusia dapat dilihat pada Tabel 4.

Tabel 4. Pemahaman Peserta Diklat terhadap Mata Diklat Badan-Badan Hak Asasi Manusia

\begin{tabular}{|l|c|c|}
\hline $\begin{array}{c}\text { Hasil } \\
\text { Pemahaman }\end{array}$ & $\begin{array}{c}\text { Sebelum } \\
\text { diklat }\end{array}$ & $\begin{array}{c}\text { Sesudah } \\
\text { diklat }\end{array}$ \\
\hline Minimum & 2,0 & 3,9 \\
\hline Maximum & 2,2 & 4,3 \\
\hline Mean & 2,1 & 4,2 \\
\hline Median & 2,1 & 4,2 \\
\hline
\end{tabular}


Tabel 4 menjelaskan tentang pemahaman peserta diklat terhadap mata diklat Badan-Badan Hak Asasi Manusia nilai pemahaman sebelum diklat nilai minimum 2,0, maximum 2,2 dengan rata-rata 2,1. Dan nilai sesudah diklat nilai minimum 3,9, maximum 4,3 dengan rata-rata 4,2.

Dari hasil uji-t di dapatkan thitung $=9,01$, P-Value $=0,000$, Standar Deviasi $=0,7850$, sedang t-tabel 0,681, dengan $\mathrm{a}=0.5$ untuk pengujian dua sisi.

Pemahaman peserta diklat tentang Badan-badan Hak Asasi Manusia lebih jelas dapat dilihat pada diagram 4.

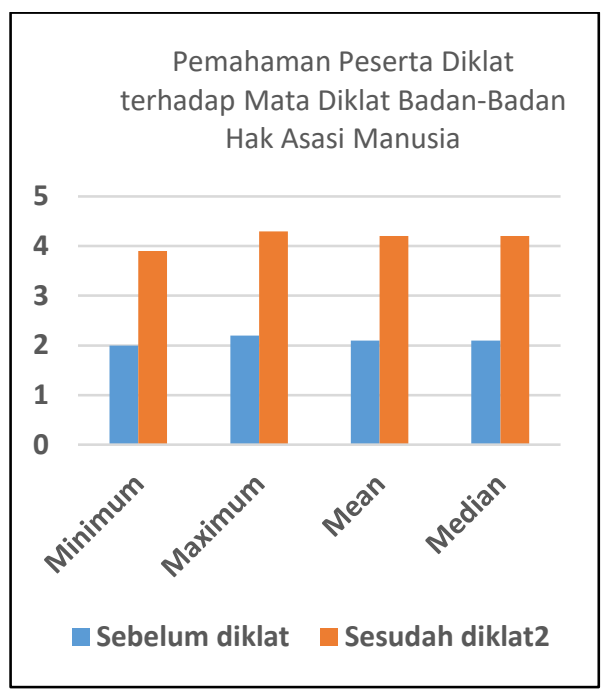

Dagram 4. Pemahaman Peserta Diklat terhadap Mata Diklat Badan-Badan Hak Asasi Manusia

Hasil angket tentang Pemahaman Peserta Diklat terhadap Mata Diklat Diklat Implementasi Pemenuhan HAM dapat dilihat pada Tabel 5.
Tabel 5. Pemahaman Peserta Diklat terhadap Mata Diklat Implementasi Pemenuhan HAM

\begin{tabular}{|l|c|c|}
\hline $\begin{array}{c}\text { Hasil } \\
\text { Pemahaman }\end{array}$ & $\begin{array}{c}\text { Sebelum } \\
\text { diklat }\end{array}$ & $\begin{array}{c}\text { Sesudah } \\
\text { diklat }\end{array}$ \\
\hline Minimum & 1,9 & 2,0 \\
\hline Maximum & 2,1 & 2,2 \\
\hline Mean & 2,0 & 2,1 \\
\hline Median & 2,0 & 2,1 \\
\hline
\end{tabular}

Tabel 5 menjelaskan tentang pemahaman peserta diklat terhadap mata diklat Implementasi Pemenuhan HAM nilai pemahaman sebelum diklat nilai minimum 2,0, maximum 2,2 dengan rata-rata 2,1 dan nilai sesudah diklat nilai minimum 1,9, maximum 2,1 dengan rata-rata 2,0.

Dari hasil uji-t di dapatkan thitung $=0,00$, P-Value $=1,000$, Standar Deviasi $=0,1003$, sedang t-tabel 0,681, dengan $a=0.5$ untuk pengujian dua sisi.

Karena t-hitung lebih kecil dari ttabel maka pemahaman peserta diklat sebelum dan sesudah dklat tidak berbeda. Terlihat hasilnya pada blokplot gambar 1 .

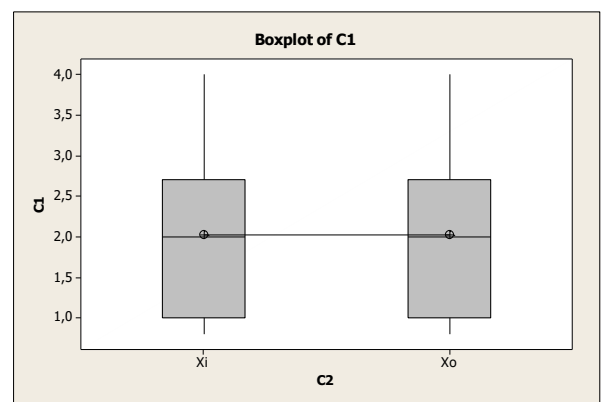

Gambar 1. Blokplot untuk uji-t Mata Diklat Implementasi Pemenuhan HAM

Untuk lebih jelasnya tentang pemahaman peserta diklat tentang Implementasi Pemenuhan HAM dapat dilihat pada diagram 5 . 


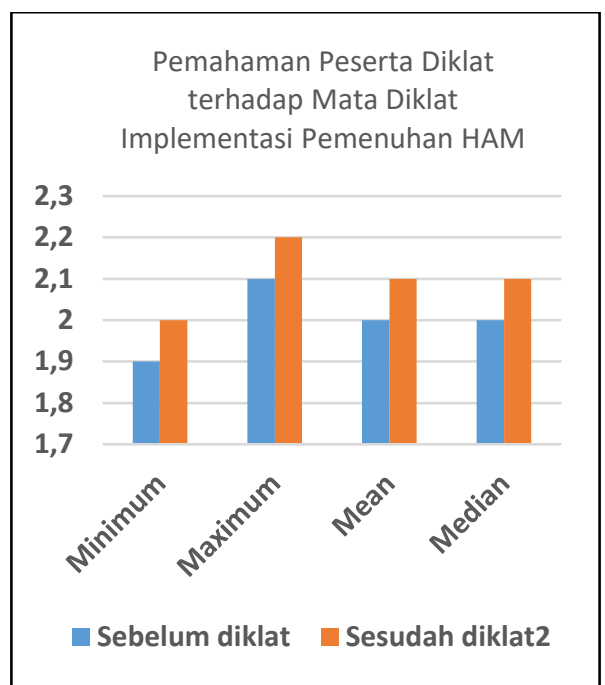

Diagram 5. Pemahaman Peserta Diklat terhadap Mata Diklat Implementasi Pemenuhan HAM

Hasil angket tentang Pemahaman Peserta Diklat terhadap Mata Diklat Pelanggaran HAM dan Mekanisme penanganannya dapat dilihat pada Tabel 6.

Tabel 6. Pemahaman Peserta Diklat terhadap Mata Diklat Pelanggaran HAM dan Mekanisme penanganannya

\begin{tabular}{|l|c|c|}
\hline $\begin{array}{c}\text { Hasil } \\
\text { Pemahaman }\end{array}$ & $\begin{array}{c}\text { Sebelum } \\
\text { diklat }\end{array}$ & $\begin{array}{c}\text { Sesudah } \\
\text { diklat }\end{array}$ \\
\hline Minimum & 1,9 & 4,1 \\
\hline Maximum & 2,1 & 4,4 \\
\hline Mean & 2,0 & 4,2 \\
\hline Median & 2,0 & 4,2 \\
\hline
\end{tabular}

Tabel 6 menjelaskan tentang pemahaman peserta diklat terhadap mata diklat Pelanggaran HAM dan Mekanisme penanganannya nilai pemahaman sebelum diklat nilai minimum 2,0, maximum 1,9 dengan rata-rata 2,0. Dan nilai sesudah diklat nilai minimum 4,1 , maximum 4,4 dengan rata-rata 4,2.
Dari hasil uji-t di dapatkan thitung $=10,31, \quad$ P-Value $=0,000$, Standar Deviasi $=0,7092$, sedang t-tabel 0,681 , dengan $a=0.5$ untuk pengujian dua sisi.

Untuk lebih jelasnya tentang pemahaman peserta diklat Pelanggaran HAM dan Mekanisme penanganannya dapat dilihat pada diagram 6 .

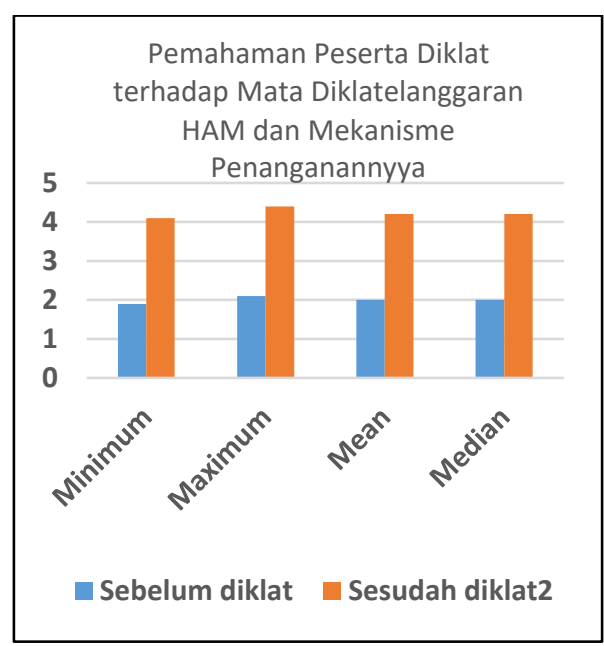

Diagram 6. Pemahaman Peserta Diklat terhadap Mata Diklat Pelanggaran HAM dan Mekanisme penanganannya

Hasil angket tentang Pemahaman Peserta Diklat terhadap Mata Diklat Manajemen Implementasi Program HAM dapat dilihat pada Tabel 7.

Tabel 7. Pemahaman Peserta Diklat terhadap Mata Diklat Manajemen Implementasi Program HAM.

\begin{tabular}{|l|c|c|}
\hline $\begin{array}{c}\text { Hasil } \\
\text { Pemahaman }\end{array}$ & $\begin{array}{c}\text { Sebelum } \\
\text { diklat }\end{array}$ & $\begin{array}{c}\text { Sesudah } \\
\text { diklat }\end{array}$ \\
\hline Minimum & 2,0 & 4,2 \\
\hline Maximum & 2,4 & 4,3 \\
\hline Mean & 2,1 & 4,2 \\
\hline Median & 2,1 & 4,2 \\
\hline
\end{tabular}


Tabel 7 menjelaskan tentang pemahaman peserta diklat terhadap mata diklat Manajemen Implementasi Program HAM. Nilai pemahaman sebelum diklat nilai minimum 2,0, maximum 2,4 dengan rata-rata 2,1. Dan nilai sesudah diklat nilai minimum 4,2, maximum 4,3 dengan rata-rata 4,2.

Dari hasil uji-t di dapatkan thitung $=10,31$, P-Value $=0,000$, Standar Deviasi $=0,7092$, sedang t-tabel 0,681 , dengan $a=0.5$ untuk pengujian dua sisi.

Lebih jelasnya tentang pemahaman peserta diklat Manajemen Implementasi Program HAM dapat dilihat pada diagram 7.

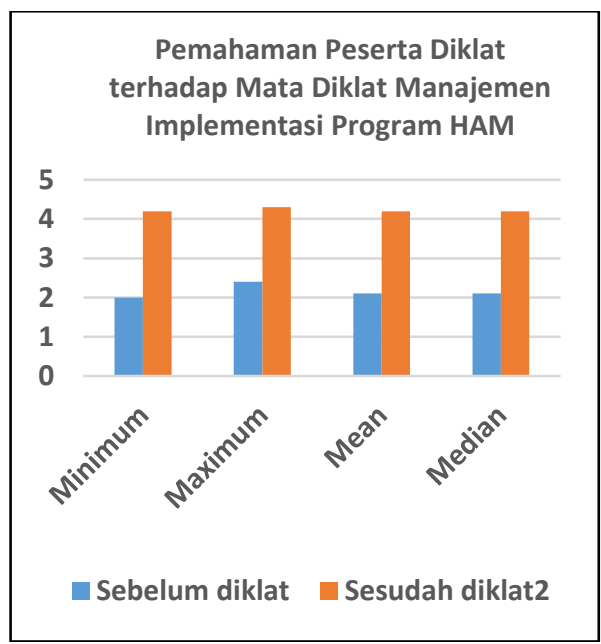

Diagram 7. Pemahaman Peserta Diklat terhadap Mata Diklat Manajemen Implementasi Program HAM

Hasil angket tentang Pemahaman Peserta Diklat terhadap Mata Diklat Menumbuhkan Budaya Organisasi dapat dilihat pada Tabel 8.
Tabel 8. Pemahaman Peserta Diklat terhadap Mata Diklat Menumbuhkan Budaya Organisasi

\begin{tabular}{|l|c|c|}
\hline $\begin{array}{c}\text { Hasil } \\
\text { Pemahaman }\end{array}$ & $\begin{array}{c}\text { Sebelum } \\
\text { diklat }\end{array}$ & $\begin{array}{c}\text { Sesudah } \\
\text { diklat }\end{array}$ \\
\hline Minimum & 2,0 & 4,3 \\
\hline Maximum & 2,1 & 4,3 \\
\hline Mean & 2,0 & 4,3 \\
\hline Median & 2,0 & 4,3 \\
\hline
\end{tabular}

Tabel 8 menjelaskan tentang pemahaman peserta diklat terhadap mata diklat Menumbuhkan Budaya Organisasi. nilai pemahaman sebelum diklat nilai minimum 2,0, maximum 2,1 dengan rata-rata 2,0 dan nilai sesudah diklat nilai minimum 4,3, maximum 4,3 dengan rata-rata 4,3. Untuk uji

Dari hasil uji-t di dapatkan thitung $=10,31, \quad$ P-Value $=0,000$, Standar Deviasi $=0,7092$, sedang t-tabel 0,681 , dengan $a=0.5$ untuk pengujian dua sisi

Untuk lebih jelasnya tentang pemahaman peserta diklat Menumbuhkan Budaya Organisasi dapat dilihat pada diagram 8.

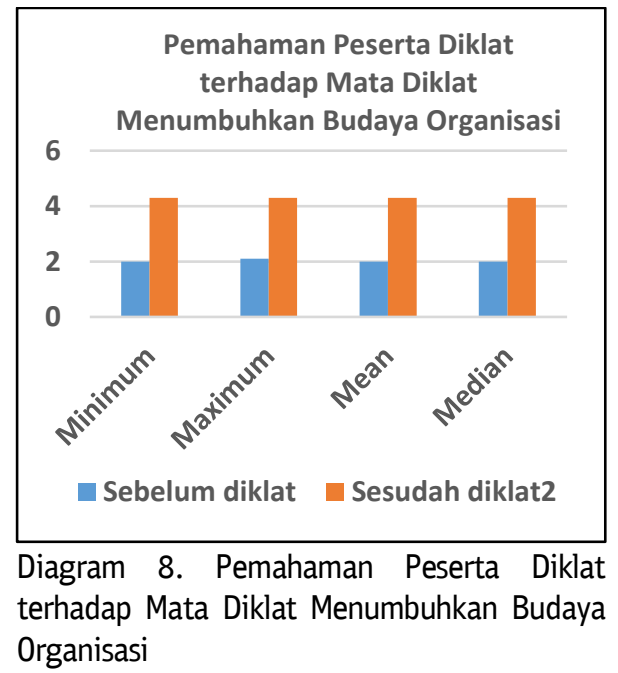


Hasil angket tentang Pemahaman Peserta Diklat terhadap Mata Diklat Kearifan Lokal, dan Kesadaran Berbangsa dan Bernegara dapat dilihat pada Tabel 9.

Tabel 9. Pemahaman Peserta Diklat terhadap Mata Diklat Kearifan Lokal, dan Kesadaran Berbangsa dan Bernegara

\begin{tabular}{|l|c|c|}
\hline $\begin{array}{c}\text { Hasil } \\
\text { Pemahaman }\end{array}$ & $\begin{array}{c}\text { Sebelum } \\
\text { diklat }\end{array}$ & $\begin{array}{c}\text { Sesudah } \\
\text { diklat }\end{array}$ \\
\hline Minimum & 2,0 & 4,3 \\
\hline Maximum & 2,0 & 4,3 \\
\hline Mean & 2,0 & 4,3 \\
\hline Median & 2,0 & 4,3 \\
\hline $\begin{array}{l}\text { Standar } \\
\text { Deviasi }\end{array}$ & 0,0 & 0,0 \\
\hline
\end{tabular}

Tabel 9 menjelaskan tentang pemahaman peserta diklat terhadap mata diklat Kearifan Lokal, dan Kesadaran Berbangsa dan Bernegara nilai pemahaman sebelum diklat nilai minimum 2,0, maximum 2,0 dengan rata-rata 2,0 serta standar deviasi 0 . Dan nilai sesudah diklat nilai minimum 4,3, maximum 4,3 dengan rata-rata 4,3 serta standar deviasi 0 .

Dari hasil uji-t di dapatkan thitung $=10,31, \quad$ P-Value $=0,000$, Standar Deviasi $=0,7092$, sedang t-tabel 0,681 , dengan $a=0.5$ untuk pengujian dua sisi

Untuk lebih jelasnya tentang pemahaman peserta diklat Kearifan Lokal, dan Kesadaran Berbangsa dan Bernegara dapat dilihat pada diagram 9.

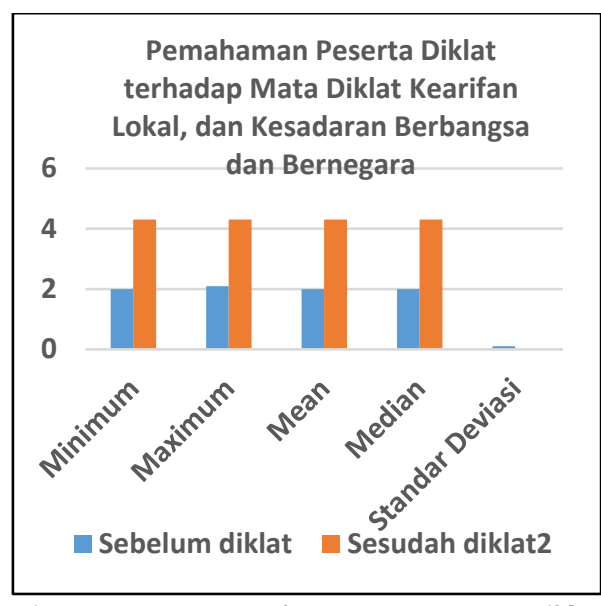

Diagram 9. Pemahaman Peserta Diklat terhadap Mata Diklat Kearifan Lokal, dan Kesadaran Berbangsa dan Bernegara

Hasil angket tentang Pemahaman Peserta Diklat terhadap Mata Diklat Metode Pembelajaran Efektif dapat dilihat pada Tabel 10.

Tabel 10. Pemahaman Peserta Diklat terhadap Mata Diklat Metode Pembelajaran Efektif

\begin{tabular}{|l|c|c|}
\hline $\begin{array}{c}\text { Hasil } \\
\text { Pemahaman }\end{array}$ & $\begin{array}{c}\text { Sebelum } \\
\text { diklat }\end{array}$ & $\begin{array}{c}\text { Sesudah } \\
\text { diklat }\end{array}$ \\
\hline Minimum & 2,1 & 4,4 \\
\hline Maximum & 2,4 & 4,5 \\
\hline Mean & 2,3 & 4,4 \\
\hline Median & 2,3 & 4,5 \\
\hline $\begin{array}{l}\text { Standar } \\
\text { Deviasi }\end{array}$ & 0,2 & 0,0 \\
\hline
\end{tabular}

Tabel 10 menjelaskan tentang pemahaman peserta diklat terhadap mata diklat Metode Pembelajaran Efektif nilai pemahaman sebelum diklat nilai minimum 2,1, maximum 2,4 dengan rata-rata 2,0 dan nilai sesudah diklat nilai minimum 4,4, maximum 4,5 dengan rata-rata 4,5. Dari hasil uji-t di dapatkan thitung $=10,31, \quad$ P-Value $=0,000$, 
Standar Deviasi $=0,7092$, sedang t-tabel 0,681 , dengan $a=0.5$ untuk pengujian dua sisi.

Untuk lebih jelasnya tentang pemahaman peserta diklat Metode Pembelajaran Efektif dapat dilihat pada diagram 10.

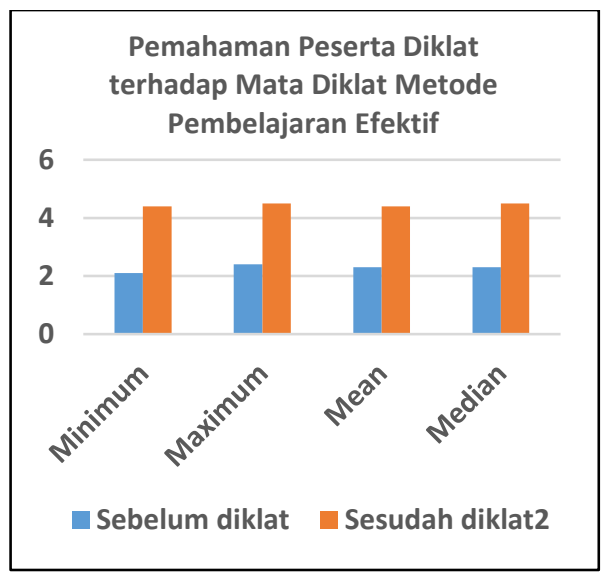

Diagram 10. Pemahaman Peserta Diklat terhadap Mata Diklat Metode Pembelajaran Efektif

Dari hasil wawancara tentang manfaat yang dirasakan oleh peserta diklat setelah mengikuti Diklat adalah mengetahui konsep dasar HAM baik Internasional dan nasional, betapa penting implementasi HAM di Madrasah, bertambah pemahaman tentang HAM, Memahami maksud dan tujuan HAM; mampu menyusun program-program yang leih baik.

Lebih lanjut dari hasil wawancara juga di dapatkan bahwa penilaian narasumber pada diklat antara lain cukup baik dan representatif sesuai bidangnya, berkompetensi dibidangnya dan profesional, sangat baik dalam pemaparan materi, motivator bagi peserta, ramah dan senyum; memiliki wawasan yang luas sehingga mampu memahami apa yang telah di sampaikan.

Setelah mengikuti diklat maka peserta diklat akan melakukan rencana tindak lanjut berupa melalui diseminasi implemenasi HAM di Madrasah, mensosialisasikan ke madrasahmadrasah, menyusun langkah program sebagai bagian dari kegiatan pendidikan di Madrasah, deseminasi dengan mengundang pihak terkait, menularkan ke guru-guru yang ada di Madrasah dan masyarakat sekitar, membuat tata tertib madrasah yang Berbasis HAM, dan mensosialisasikan pendidikan HAM pada lingkungan madrasah selanjutnya mengimplementasikan Madrasah Ramah Anak.

\section{Pembahasan}

Dari hasil pengolahan data secara statistik deskriptif dan uji-t di atas maka dapat dianalisis antara lain:

a. Mata Diklat Konsep dasar HAM

Untuk mata diklat ini yang materinya terdiri dari Pengertian HAM, Karakteristik HAM; Nilai-nilai HAM, Ruang lingkup HAM; Sejarah perkembangan HAM internasional; Prinsip HAM dalam hukum internasional, Subyek hukum HAM; Sumber hukum HAM; Pelanggaran HAM; Pertanggungjawaban negara pada awalnya pemahaman peserta diklat masih kurang dengan rata-rata 2,0 (kurang). Sedangkan peningkatan pemahaman peserta diklat cukup signifikan yaitu menjadi 4,2 (sangat baik). Dan t-hitung lebih besar dari t-tabel maka pemahaman 
peserta diklat sebelum dan sesudah diklat meningkat secara signifkan.

b. Mata Diklat Instrumen Nasional HAM

Untuk mata diklat ini yang terdiri dari materi Hak untuk hidup; Hak berkeluarga, Hak melanjutkan keturunan; Hak mengembangkan diri; Hak kebebasan pribadi; Hak Kebebasan Pribadi; dan Hak atas rasa aman pada awalnya pemahaman peserta diklat sudah cukup dengan rata-rata 2,6 (cukup). Sedangkan peningkatan pemahaman peserta diklat cukup signifikan yaitu menjadi 4,4 (sangat baik). Nilai t-hitung lebih besar dari t-tabel maka pemahaman peserta diklat sebelum dan sesudah diklat meningkat secara signifkan.

c. Mata Diklat Instrumen Internasional HAM (The Internasional Bill of human Rights)

Untuk mata diklat ini materi tentang The International Bill of Human Rights; Deklarasi universal Hak-Hak Asasi Manusia, Kekuatan hukum deklarasi universal Hak Asasi Manusia pada awalnya pemahaman peserta diklat masih kurang dengan rata-rata 1,9 (kurang). Sedangkan peningkatan pemahaman peserta diklat cukup signifikan yaitu menjadi 4,2 (sangat baik). Dan t-hitung lebih besar dari t-tabel maka pemahaman peserta diklat sebelum dan sesudah diklat meningkat secara signifkan

d. Mata Diklat Badan-Badan Hak Asasi Manusia

Untuk mata diklat ini terdiri dari materi Badan-badan Hak Asasi Manusia PBB; Badan-badan yang didirikan Berdasarkan Instrumen- instrumen Hak Asasi Manusia; Badanbadan Khusus PBB, Badan-badan Nasional Hak Asasi Manusia pada awalnya pemahaman peserta diklat masih kurang dengan rata-rata 2,1 (kurang). Sedangkan peningkatan pemahaman peserta diklat cukup signifikan yaitu menjadi 4,2 (sangat baik). Kemudian nilai t-hitung juga lebih besar dari t-tabel maka pemahaman peserta diklat sebelum dan sesudah diklat meningkat secara signifkan.

e. Mata Diklat Implementasi Pemenuhan HAM

Untuk mata diklat ini materinya antara lain Jaminan implementasi pemenuhan HAM, Mekanisme kerja implementasi pemenuhan HAM; Implementasi HAM; Evaluasi dan pelaporan; Permasalahan strategis, rencana aksi, indikator implementasi pemenuhan HAM pada awalnya pemahaman peserta diklat masih kurang dengan rata-rata 2,0 (kurang). Sedangkan peningkatan pemahaman peserta diklat hanya 0,1 yaitu menjadi 2,1 (kurang).

Nilai t-hitung lebih kecil dari ttabel maka pemahaman peserta diklat sebelum dan sesudah diklat tidak berbeda.

f. Mata Diklat Pelanggaran HAM dan Mekanisme penanganannya

Untuk mata diklat ini, terdiri dari materi Pengertian pelanggaran HAM; Pelanggaran HAM dalam perspektif instrumen nasional; Pelanggaran HAM dalam perspektif instrumen internasional; Pertanggungjawaban Negara atas terjadinya pelanggaran 
$\begin{array}{lrr}\text { HAM; } & \text { Pertanggungjawaban } \\ \text { Individual } & \text { atas } & \text { terjadinya } \\ \text { pelanggaran } & & \text { HAM, }\end{array}$

Pertanggungjawaban Komando atas terjadinya pelanggaran HAM; Pengadilan Hak Asasi Manusia atas terjadinya pelanggaran HAM, Mekanisme penanganan pelanggaran HAM Berat; serta Peran Ditjen HAM Kementerian Hukum dan HAM RI dalam penanganan pelanggaran pada awalnya pemahaman peserta diklat masih kurang dengan rata-rata 2,0 (kurang). Sedangkan peningkatan pemahaman peserta diklat cukup signifikan yaitu menjadi 4,2 (sangat baik).

Dan t-hitung lebih besar dari ttabel maka pemahaman peserta diklat sebelum dan sesudah diklat meningkat secara signifkan.

g. Mata Diklat Manajemen Implementasi Program HAM

Untuk mata diklat ini materinya adalah Penyusunan rencana implementasi program HAM; Implementasi program HAM, Control terhadap implementasi program HAM, Evaluasi implementasi program HAM pada awalnya pemahaman peserta diklat masih kurang dengan rata-rata 2,0 (kurang). Sedangkan peningkatan pemahaman peserta diklat cukup signifikan yaitu menjadi 4,2 (sangat baik). Dan t-hitung lebih besar dari ttabel maka pemahaman peserta diklat sebelum dan sesudah diklat meningkat secara signifkan.

h. Mata Diklat Menumbuhkan Budaya Organisasi
Untuk mata diklat ini terdiri dari indikator materi Budaya organisasi berbasis HAM; Kearifan Lokal, dan Kesadaran Berbangsa dan Bernegara, Konsep kearifan lokal; kesadaran berbangsa dan bernegara; Pentingnya budaya lokal dalam membangun kesadaran berbangsa dan bernegarapada awalnya pemahaman peserta diklat masih kurang dengan rata-rata 2,0 (kurang). Sedangkan peningkatan pemahaman peserta diklat cukup signifikan yaitu menjadi 4,3 (sangat baik). Dan t-hitung lebih besar dari ttabel maka pemahaman peserta diklat sebelum dan sesudah diklat meningkat secara signifkan.

i. Mata Diklat Kearifan Lokal, dan Kesadaran Berbangsa dan Bernegara

Untuk mata diklat ini terdiri dari indikator materi Budaya organisasi berbasis HAM; Kearifan Lokal, dan Kesadaran Berbangsa dan Bernegara, Konsep kearifan lokal; kesadaran berbangsa dan bernegara; Pentingnya budaya lokal dalam membangun kesadaran berbangsa dan bernegara pada awalnya pemahaman peserta diklat masih kurang dengan rata-rata 2,0 (kurang). Sedangkan peningkatan pemahaman peserta diklat cukup signifikan yaitu menjadi 4,3 (sangat baik). Dan t-hitung lebih besar dari ttabel maka pemahaman peserta diklat sebelum dan sesudah diklat meningkat secara signifkan.

j. Mata Diklat Metode Pembelajaran Efektif

Untuk mata diklat ini terdiri dari indikator materi antara lain Konsep, 
asumsi dasar dan prinsip pembelajaran orang dewasa; Metode dan strategi efektif dalam pembelajaran HAM; Simulasi metode efektif dalam pembelajaran HAM pada awalnya pemahaman peserta diklat masih kurang dengan rata-rata 2,3 (kurang). Sedangkan peningkatan pemahaman peserta diklat cukup signifikan yaitu menjadi 4,4 (sangat baik). Dan t-hitung lebih besar dari t-tabel maka pemahaman peserta diklat sebelum dan sesudah diklat meningkat secara signifkan

Nilai standar deviasi dari 10 (sepuluh) data pemahaman tentang mata diklat yang diterima oleh peserta diklat menunjukkan bahwa kumpulan data menunjukkan perbedaan antara 0-0,7 yang menunjukkan bahwa semua nilainilai dalam himpunan tersebut adalah hampir sama. Apabila nilai deviasi kecil maka berarti titik data peresponden mendekati rata-rata begitu sebaliknya apabila sebuah nilai deviasi yang lebih besar akan memberikan makna bahwa titik data individu jauh dari nilai ratarata.

Sedangkan dari sepuluh mata diklat di atas terlihat bahwa Mata Diklat Konsep dasar HAM peningkatan pemahaman sangat baik dari sebelum menerima pelatihan dan setelah pelatihan dari kurang paham menjadi sangat baik pemahamannya. Begitu juga dengan mata diklat ke-2 tentang Instrumen Nasional HAM, mata diklat ke3 yaitu Instrumen Internasional HAM (The Internasional Bill of human Rights), mata diklat ke-4 yaitu Badan-Badan Hak Asasi Manusia, mata diklat ke-6 yaitu
Pelanggaran HAM dan Mekanisme penanganannya, mata diklat ke-7 yaitu Manajemen Implementasi Program HAM, mata diklat ke-8 yaitu Menumbuhkan Budaya Organisasi, mata diklat ke-9 yaitu Kearifan Lokal, dan Kesadaran Berbangsa dan Bernegara, dan mata diklat ke-10 yaitu Metode Pembelajaran Efektif.

Hal ini sesuai dengan hasil penelitian Hidayat \& Nurasyiah (2017:81) bahwa terdapat pengaruh yang kuat antara diklat (pendidikan dan pelatihan) dengan prestasi kerja yang dapat diartikan adanya pengaruh yang signifikan diklat (pendidikan dan pelatihan) terhadap prestasi kerja karyawan. Pelatihan mampu meningkatkan kinerja karyawan mengenai pelatihan dan kinerja yang menyatakanbahwa pelatihan berpengaruh signifikan terhadap kerja karyawan. Dengan demikian dapat disimpulkan bahwa dengan adanya pelatihan kerja seseorang sudah terlatih bakatnya sehingga dalam bekerja ia lebih dapat mengembangkan bakat yang dimilikinya tersebut sesuai dengan kemampuannya.

Pelatihan juga akan berdampak pada peningkatan kerja karyawan yang secara langsung mempengaruhi kinerja perusahaan. Pelatihan mempunyai pengaruh yang besar dalam menentukan efektifitas dan efisiensi organisasi, karena pelatihan dapat membantu karyawan untuk bekerja dengan lebih baik lagi. Apabila pelatihan yang telah dilaksanakan telah sesuai dengan kebutuhan dan telah mencapai sasaran maka akan dapat meningkatkan kinerja pegawai yang kemudian akan yang jauh lebik baik dari sebelumnya (Mandang \& dkk. 2017: 4322). 
Sedangkan untuk mata diklat ke-2 tentang Instrumen Nasional HAM yaitu peningkatan pemahamannya sebelum mengikuti diklat dari cukup meningkat menjadi sangat baik. Tapi untuk mata diklat ke-5 tentang implementasi Pemenuhan HAM yang materinya Jaminan implementasi pemenuhan HAM, Mekanisme kerja implementasi pemenuhan HAM; Implementasi HAM; Evaluasi dan pelaporan; Permasalahan strategis, rencana aksi, indikator implementasi pemenuhan HAM pada awalnya pemahaman peserta diklat seelum maupun sesudah diklat samasama masih kurang dengan rata-rata 2,0 (kurang) menjadi 0,1, jadi peningkatan pemahaman peserta diklat hanya 0,1. Dan t-hitung lebih kecil dari t-tabel maka disimpulkan pemahaman peserta diklat sebelum dan sesudah diklat tidak berbeda.

Secara keseluruhan dari hasil wawancara terstruktur, peserta diklat menyatakan bahwa narasumber yang melakukan proses pembelajaran di kelas mempunyai kompetensi yang bagus, motivator dan menjadikan pembelajaran yang menyenangkan.

\section{PENUTUP}

\section{Simpulan}

Terdapat peningkatan pemahaman yang signifikan peserta diklat Diklat
Teknis Substantif HAM bagi Kepala Madrasah sebelum menerima pelatihan dan setelah pelatihan dari kurang paham menjadi sangat baik pemahamannya pada mata diklat Konsep dasar HAM, mata diklat Instrumen Nasional HAM, mata diklat Instrumen Internasional HAM (The Internasional Bill of human Rights), mata diklat Badan-Badan Hak Asasi Manusia, mata diklat Pelanggaran HAM dan Mekanisme penanganannya, mata diklat Manajemen Implementasi Program HAM, mata diklat Menumbuhkan Budaya Organisasi, mata diklat Kearifan Lokal, dan Kesadaran Berbangsa dan Bernegara, dan mata diklat Metode Pembelajaran Efektif. Mata diklat ke-5 tentang implementasi Pemenuhan HAM tidak terdapat peningkatan pemahaman yang signifikan peserta diklat Diklat Teknis Substantif HAM bagi Kepala Madrasah sebelum menerima pelatihan dan setelah pelatihan.

\section{Rekomendasi}

a. Adanya perbaikan proses diklat untuk materi instrumen nasional HAM baik dari segi narasumber maupun faktor lain yang mendukung

b. Adanya rencana tindak lanjut yang nyata di lapangan oleh peserta diklat

c. Evaluasi dan perbaikan diklat secara berkelanjutan untuk peningkatan mutu. 


\section{DAFTAR PUSTAKA}

Bass, Issa. 2007. Six Sigma Statistics. USA: McGraw-Companies, Inc

Hidayat \& Nurasyiah. 2017. "Pengaruh Diklat (Pendidikan dan Pelatihan) terhadap Prestasi Kerja Karyawan di Bank BPR Rokan Hulu." Jurnal Ilmiah Cano Ekonomos Vol. 6 No. 1 Januari 2017. Rokan hulu: Fakultas Ekonomi Universitas Pasir Pengaraian. https://media.neliti.com/media/publications/59148-ID-pengaruh-diklatpendidikan-dan-pelatihan.pdf

Mandang, Evert Fandi \& dkk. 2017. Pengaruh Tingkat Pendidikan dan Pelatihan Terhadap Kinerja Karyawan pada PT. Bank Rakyat Indonesia (Persero), Tbk Cabang Manado. Manado: Fakultas Ekonomi dan Bisnis, Jurusan Manajemen Universitas Sam Ratulangi Manado.Jurnal EMBA Vol.5 No.3 September 2017, Hal.4324-4335. file:///C:/Users/thosiba/Downloads/ 1842737192-1-SM.pdf

Naning, Ramdlon. 1982. Gatra Ilmu Negara. Yogyakarta : Penerbit Liberty

Reksodiputro, Marjono. 1994. Hak Asasi manusia Dalam Sistim Peradilan Pidana. Kumpulan Karangan Buku III. Jakarta: Penerbit Pusat Pelayanan Keadilan dan Bantuan Hukum Universitas Indonesia

Sugiyono. 2010. Statistika Untuk Penelitian. Bandung: Penerbit Alfabeta

Sukardi.2008. Metodologi Penelitian Pendidikan: Kompetensi dan Praktiknya. Jakarta: Bumi Aksara

Sumana, Yudana. 1970. Hak-hak Azasi Manusia. Jakarta: Penerbit PT.Gunung Agung,

Supriyanto Abdi, 2007. "Mengurai Hubungan Kompleksitas Islam, HAM, dan Barat" dalam UNISIA. Yogayakarta: UII Press, No. 44/XXV/I/2002)

Utari, Ni Ketut Sri. 2016. Buku Ajar: Hukum Hak Asasi Manusia. Denpasar: Fakultas hukum Unversias Udayana

Wahab, Abdul dan Lestari, Lies Amin. 1999. Menulis Karya Ilmiah. Surabaya: Airlangga University Press.

Winardi, Gunawan. 2002. Panduan Mempersiapkan Tulisan Ilmiah. Bandung: Akatiga. Yonesta, Febi.,dkk. 2012. Agama, Negara dan Hak Azazi Manusia. Jakarta: LBH

Yuliarso, Kurniawan Kunto \& Prajarto, Nunung. 2005. "Hak Asasi (HAM) di Indonesia: Menuju Democratic Governances. " Jurnal Ilmu Sosal dan Ilmu Politik. Volume 8, Nomor 3. file:///C:/Users/thosiba/Downloads/ 11046-21064-1-PB.pdf 